Научная статья

УДК $82-32$

DOI 10.18101/2686-7095-2021-4-10-14

\title{
ЖАНРОВАЯ МОДЕЛЬ \\ РАССКАЗА Ф. М. ДОСТОЕВСКОГО «ПОЛЗУНКОВ»
}

\author{
(C) Бабичева Юлия Геннадьевна \\ кандидат филологических наук, доцент, \\ заведующая кафедрой русского языка и литературы, \\ Алтайский государственный гуманитарно-педагогический университет \\ имени В. М. Шукшина \\ Россия, 659333, г. Бийск, ул. Владимира Короленко, 53 \\ liraff1@yandex.ru
}

\begin{abstract}
Аннотация. В статье исследуется жанровая модель рассказа Ф. М. Достоевского «Ползунков» как одна из самых синтетичных художественных форм в литературе классического периода. Выявлены и описаны ее основные черты, связанные, с одной стороны, с развитием общелитературных тенденций критического реализма 40-х гг. XIX в., с другой - с индивидуально авторскими художественными интенциями, сказовым, опосредованным повествованием, во многом обусловленным полифонизмом прозы писателя. Особое внимание уделяется образу главного героя, актуализирующего архетипический пласт рассказа, который является ядром его жанровой модели и создает мощное интертекстуальное и аксиологическое поле. Подчеркивается концептуальная значимость обозначенной модели в эволюции художественного мира Ф. М. Достоевского, в конструировании его романной формы.

Ключевые слова: жанровая модель, жанровый синтез, рассказ, сказовость, интертекст, мифологема, архетип, шут, юродивый, амбивалентность.
\end{abstract}

\section{Для цитирования}

Бабичева Ю. Г. Жанровая модель рассказа Ф. М. Достоевского «Ползунков» // Вестник Бурятского государственного университета. Филология. 2021. Вып. 4. С. 10-14.

Актуальность исследования обусловлена вниманием современной филологической науки к рецепции жанровых моделей художественной литературы. На наш взгляд, одной из наиболее синтетичных форм, отличающейся размытостью жанровых границ, является рассказ. Именно он, будучи достаточно традиционной структурой, подчеркивает специфику как индивидуально авторских художественных интенций, так и общелитературных трансформаций историкокультурной эпохи.

Важно обратиться к жанру рассказа классического периода, ведь первая половина XIX в. считается периодом кардинальной трансформации жанровой системы. Справедливо отметила И. Ю. Погорелова, что «металитературные мотивы, характерные для указанного времени, свидетельствуют о структурной перестройке художественного мышления, воплотившейся в процессах взаимопроникновения, смешения жанров, их деканонизации и романизации (термин Бахтина)» [6]. Жанр, закрепляя принципы построения произведения как завершенного художественного целого, выполняет важнейшую моделирующую функцию. Он как бы цементирует особенности художественного мира творца, демон- 
стрируя вместе с тем историю его эволюции. Не случайно многие романисты XIX в. начинали свой творческий путь с малой прозы, а далее осваивали крупные эпические формы.

Для нас важно определение Л. И. Тимофеева: рассказ — это «небольшое художественное произведение, посвященное обычно отдельному событию в жизни человека, без детального изображения того, что с ним было до и после этого события» [8, с. 77]. Развивает эту мысль А. Миловер: рассказ - «это небольшое прозаическое произведение с одним или двумя основными героями, посвященное изображению какого-то одного события... Цель написания рассказа: передать некоторую мысль, а не рассказать о каком-либо событии или герое». Он же опирается на критика Е. Аничкова: «в центре рассказов стоит именно личность человека, а не целая группа людей» [2]. Ориентируясь на последний тезис, хочется обратиться к наследию Ф. М. Достоевского. Именно Человек стоит в центре художественной системы известного русского классика. И здесь отправной точкой его идейно-эстетических поисков, воплощенных прежде всего в «великом пятикнижии», становится малая проза 1840-х - 1850-х гг.

Обратимся к жанровой модели рассказа «Ползунков», созданного в 1847 г. Она выстраивается в результате анализа двух аспектов - формы повествования и событийного компонента, представленного единством организации художественного пространства и времени.

С точки зрения формы, «Ползунков» - достаточно классический «рассказ в рассказе», восходящий к традиции «физиологического очерка» XIX в.: рисуется легко узнаваемый чиновничий мир взяточничества, корысти, обмана и лжи. Вместе с тем произведение нарочито разрушает традиционную модель рассказа, намечая сюжетные линии последующих, романных, произведений Ф. Достоевского [2]. Форма «рассказа в рассказе», воплощающая модель опосредованного повествования, является яркой чертой эстетической системы Ф. М. Достоевского. Во многом она создает полифонизм прозы писателя, не только организующий дискуссионное поле героев-идеологов, но размыкающий границы повествования уже в ранней малой прозе. Речевая организация повествования в рассказе «Ползунков» позволяет заключить, что жанровая модель произведения плотно насыщена сказовыми элементами, репрезентирующими речь городского чиновника. По сути, все повествование - это поток речи, воспроизводящий компоненты «своего» и «чужого» дискурса. Таким образом, «сказовость» прочно входит в систему элементов создания полифонического поля.

Традиционная модель «повествования от лица рассказчика», заданная в начале текста, усложняется по ходу разворачивания сюжета внедрением новой художественной составляющей - перформанса главного героя, театрально демонстрирующего историю своей неудачной попытки изменить свой социальный статус. Драма героя, «даже немного трагическая» [1], явственно отсылает читателя к комедии А. С. Грибоедова «Горе от ума», задавая рассказу, с одной стороны, социально-бытовой тон звучания, с другой - погружая во внутренний конфликт. Подобная двуплановость четко соотносится с идейно-эстетическими интенциями автора-психолога, исследовавшего сложность натуры рядового чиновника. Эту мысль поддерживает многомерность трагикомического образа Осипа Ползункова, уводящая в зону раскрытия архетипического плана рассказа. 
Еще в 1980-х гг. в работах И. П. Смирнова архетипы были рассмотрены с точки зрения жанрологии. Ученый связывал архетипичность с теорией интертекстуальности: «продуцируемый текст повторяет архетипическую тему сопряженных с ним претекстов» [7]. Ассоциативный компонент жанра манифестируется в системе интертекстуальных связей, репрезентируя архаический пласт художественного текста. Архетипическая ситуация становится ядром жанровой модели рассказа Ф. М. Достоевского, максимально расширяя его художественное пространство.

Как отмечал К. Г. Юнг в работе «Архетип и символ», «момент возникновения мифологической ситуации всегда характеризуется особенной эмоциональной интенсивностью» [9]. Начало рассказа Достоевского полностью соответствует этой методологической установке: автор-рассказчик рисует не привычные пространственно-временные координаты (место и время происходящего события), а сразу живое лицо, как будто бы спонтанно вплетенное в повествовательную ткань текста и вместе с тем занимающее центральное место в нарративе. Его архетипичность ярко задана уже в первом абзаце произведения.

Ползунков раскрывается не просто как тип «маленького человека», а скорее архетип шута-юродивого, нагруженный «змеиной» семантикой (Ползунков ползать, Осип - осипнуть - шипеть - змея): его вечная подвижность и поворотливость («жируэтка»), умение заставлять «приковываться к нему взглядом» [1] (как при змеином гипнозе) делают его центром внимания публики. Как известно, змея - один из самых амбивалентных мифологических образов. Такая же двойственность отличает и Ползункова: он и шут, и юродивый одновременно. В его поведении много театрального, подкрепляемого мотивом игры и переодевания-перевоплощения: «...снял бы фрак свой, надел его как-нибудь наизнанку и пошел бы в этом наряде, другим в угоду, а себе в наслаждение, по улицам...» [1]. Главный герой - маленький человек, за комическим обличием которого, по замечанию О. Г. Левашовой, обнаруживается «трагическая сущность характера, самолюбивого и порой великодушного, несомненно, раздвоенного, глубоко страдающего от несправедливости окружающего мира, минутами возвышающегося до протеста: «Нужно было видеть и слышать, как он умел отделать, иногда не щадя себя, следовательно с риском, почти с геройством, кого-нибудь из своих покровителей, уже донельзя его разбесившего... Хула на сильных мира сего сближает Ползункова с юродивым, что и подчеркивается внешним обликом героя, которому соответствует зрелищная сторона этого архаического смехового явления культуры Древней Руси» [5]. Синтез шутовского поведения и честолюбивых исканий, демонстрируемый Ползунковым, создает характер, представляющий и социально-психологический, и архетипический интерес.

Таким образом, в «Ползункове» Ф. М. Достоевского манифестированы некоторые малой прозы писателя: архетипическая составляющая с ее мощным интертекстуальным и аксиологическим полем, ориентация на опосредованное повествование в сказовом стиле, которое станет основой диалогов романных персонажей писателя, полилинейность событийного плана, меняющая традиционное представление о сюжете рассказа. 


\section{Литература}

1. Достоевский Ф. М. Собрание сочинений: в 15 т. Т. 2. Повести и рассказы. Ленинград: Наука. Ленингр. отд-е, 1848-1852. URL: https://rvb.ru/dostoevski/01text/vol2/08.htm (дата обращения: 28.09.2021). Текст: электронный.

2. Достоевский: Эстетика и поэтика: словарь-справочник / составители Г. К. Щенников, А. А. Алексеев; научный редактор Г. К. Щенников. Челябинск: Металл, 1997. 270 с. Текст: непосредственный.

3. Миловер А. Определение жанра рассказа. URL: http://www.proza.ru/2012/10/22/1995 (дата обращения: 28.09.2021). Текст: электронный.

4. Мифологический словарь / главный редактор Е. М. Метелинский. Москва: Сов. Энциклопедия, 1990. 672 с. Текст: непосредственный.

5. Левашова О. Г. К вопросу о генезисе «странного» героя Ф. М. Достоевского и B. М. Шукшина. URL: https://cyberleninka.ru/article/n/k-voprosu-o-genezise-strannogogeroya-f-m-dostoevskogo-i-v-m-shukshina/viewer (дата обращения: 28.09.2021). Текст: электронный.

6. Погорелова И. Ю. Категория жанра в литературоведческой парадигме. URL: https://pgu.ru/upload/iblock/111/kategoriya-zhanra-v-lit.paradigme.pdf (дата обращения: 28.09.2021). Текст: электронный.

7. Смирнов И. П. Порождение интертекста: Элементы интертекстуального анализа с примерами из творчества Б. Л. Пастернака / С.-Петерб. гос. ун-т. 2-е изд. СанктПетербург: Языковый центр СПбГУ, 1995. 189 с. Текст: непосредственный.

8. Тимофеев Л. И., Венгеров Н. Краткий словарь литературоведческих терминов. Москва, 1963. 100 с. Текст: непосредственный.

9. Юнг К. Г. Архетип и символ. Москва: Ренессанс, 1991. 304 с. Текст: непосредственный.

10. Юнг К. Г. Душа и миф: шесть архетипов: перевод с английского. Киев: Государственная библиотека Украины для юношества, 1996. 384 с. Текст: непосредственный.

Статья поступила в редакцию 19.11.2021; одобрена после рецензирования 29.11.2021; принята к публикации 10.12.2021.

\section{GENRE MODEL \\ OF FYODOR DOSTOEVSKY'S SHORT STORY "POLZUNKOV"}

Yulia G. Babicheva

Cand. Sci. (Phil.), A/Prof.,

Head of the Russian Language and Literature,

Shukshin Altai State University for Humanities and Pedagogy

53 Vladimir Korolenko St., Biysk 659333, Russia

Absract. The article analyzes a genre model of Fyodor Dostoevsky's short story "Polzunkov" as one of the most synthetic artistic forms in the literature of the classical period. We have identified and described the main features of this model, associated, on the one hand, with the development of general literary tendencies of critical realism in the 1840 s, and on the other, with author's individual artistic intentions, as well as intermediary narration, to a great extent determined by polyphonism of the writer's prose. Special attention has been paid to the image of the protagonist, who actualizes the archetypal layer of the story, which is the core of its genre model and creates a powerful intertextual and axiological field. We emphasize the conceptual significance of the created model in the evolution of Fyodor Dostoevsky's artistic world, and construction of his novelistic form. 
ВЕСТНИК БУРЯТСКОГО ГОСУДАРСТВЕННОГО УНИВЕРСИТЕТА.

Keywords: genre model, genre synthesis, short story, narrativeness, intertext, mythologeme, archetype, fool; holy fool; ambivalence.

For citation

Babicheva Yu. G. Genre Model of Fyodor Dostoevsky's Short Story "Polzunkov". Bulletin of Buryat State University. Philology. 2021; 4: 10-14 (In Russ.).

The article was submitted 19.11.2021; approved after reviewing 29.11.2021; accepted for publication 10.12.2021. 